\title{
Rituximab Induction and Maintenance in ANCA-Associated Vasculitis: State of the Art and Future Perspectives
}

\author{
Elena Treppo, Marco Binutti, Roberto Agarinis, Salvatore De Vita and Luca Quartuccio *(D) \\ Department of Medicine, Rheumatology Clinic, University of Udine, ASUFC, 33100 Udine, Italy; \\ treppo.elena@gmail.com (E.T.); m.binutti@stdelta.com (M.B.); agarinis.roberto@gmail.com (R.A.); \\ salvatore.devita@uniud.it (S.D.V.) \\ * Correspondence: luca.quartuccio@uniud.it; Tel.: +39-0432559808
}

check for updates

Citation: Treppo, E.; Binutti, M.; Agarinis, R.; De Vita, S.; Quartuccio, L. Rituximab Induction and

Maintenance in ANCA-Associated Vasculitis: State of the Art and Future Perspectives. J. Clin. Med. 2021, 10, 3773. https://doi.org/10.3390/ jcm10173773

Academic Editors: Olivier Morel and George N. Kouvelos

Received: 15 June 2021

Accepted: 20 August 2021

Published: 24 August 2021

Publisher's Note: MDPI stays neutral with regard to jurisdictional claims in published maps and institutional affiliations.

Copyright: (c) 2021 by the authors. Licensee MDPI, Basel, Switzerland. This article is an open access article distributed under the terms and conditions of the Creative Commons Attribution (CC BY) license (https:/ / creativecommons.org/licenses/by/ $4.0 /)$.

\begin{abstract}
Antineutrophil cytoplasmatic antibody (ANCA)-associated vasculitis (AAV) is a group of rare autoimmune diseases characterized by inflammation of the vascular wall. The pathogenesis of AAV is strongly associated with B cell-derived ANCAs; thus, Rituximab (RTX) has become a promising drug in the induction and maintenance treatment of AAV. The purpose of this review is to describe the efficacy and safety of RTX in the induction of remission and maintenance therapy of AAV. Herein, we summarize the randomized controlled trials that have contributed to the refinement of the use of RTX in AAV in the past decades. RTX has been proven to be effective both in new-onset disease and in relapsing disease. Although the optimal duration of AAV maintenance therapy remains unknown, the ANCAs and the B-cell repopulation may offer support for the administration of further RTX cycles (or not). The safety of RTX is comparable with cyclophosphamide, with the advantage of a low risk of malignancy and no concern for fertility. In conclusion, RTX now plays an important role in the induction and maintenance therapy of AAV. Optimizing RTX-based treatment strategies in $\mathrm{AAV}$ is one of the main goals of the current research in AAV.
\end{abstract}

Keywords: vasculitis; ANCA; rituximab; B cell

\section{Clinical Features and Relevance of ANCA in AAV}

Antineutrophil cytoplasmatic antibody (ANCA)-associated vasculitis (AAV) is a smallsized blood vessel vasculitis. AAV encompasses a heterogeneous group of rare autoimmune diseases represented by granulomatosis with polyangiitis (GPA), microscopic polyangiitis (MPA), and eosinophilic granulomatosis with polyangiitis (EGPA) [1,2]. The terminology is linked to the presence of circulating autoantibodies, namely ANCAs, which are directed against the antigens found in the granules of neutrophils, most commonly either proteinase 3 (PR3) or myeloperoxidase (MPO) [3]. Typically, PR3-ANCA is detected in GPA (80-90\% of patients), and MPO-ANCA is detected in MPA (60-85\% of patients) [3]. In EGPA, the presence of ANCA shows more variability (30-60\% of patients) and mainly involves MPO-ANCA [3]. AAV is a rare disease and in recent decades, several studies on its incidence and prevalence have been conducted, reporting a progressive worldwide increase [4]. Globally, the annual incidence ranges from 1.2 to 3.3 cases per 100,000 individuals, and the prevalence of AAV ranges from 4.6 to 42.1 cases per 100,000 individuals [4]. There is no clear gender predominance, though a slight male predominance among MPA compared to GPA has been reported [5,6]. Significant geographic differences have been reported among AAV subgroups, emphasising how the incidence of GPA and EGPA increases with latitude [7]. MPO-AAV and MPA are more common in Japan. PR3-AAV and GPA are more common in Europe [4]. ANCA specificity has a growing interest in the scientific community; in fact, it may fit better than clinical diagnosis for defining homogeneous groups of patients as well as for relapsing disease and clinical outcome [2].

Although AAV is a rare disease and its prevalence is geographically heterogeneous, recent studies concerning the healthcare burden of AAV reveal a high level of economic 
source consumption for the healthcare system [8,9]. Considering the wide spectrum of AAV organ manifestations, it is not surprising that the major cost component is the high rate of hospitalization. AAV can lead to a wide range of clinical manifestations; Table 1 shows possible multi-organ involvement. Involvement ranges from mild, such as ear, nose, and throat (ENT), to potentially life-threatening, such as alveolar haemorrhage [10].

Table 1. Clinical and laboratory characteristics of patients with antineutrophil cytoplasmatic antibody (ANCA)associated vasculitis.

\begin{tabular}{|c|c|c|c|}
\hline Clinical Manifestations & MPA & GPA & EGPA \\
\hline \multirow{2}{*}{ Constitutional symptoms } & \multicolumn{3}{|c|}{ Fever, Weight Loss, Fatigue, Arthralgia, Myalgia } \\
\hline & $55-80 \%$ & $70-100 \%$ & $30-50 \%$ \\
\hline \multirow{2}{*}{ Skin } & \multicolumn{3}{|c|}{ Palpable Purpura, Nodules, Pseudourticarial Rash, Livedo Reticularis, Ulcers } \\
\hline & $35-60 \%$ & $10-50 \%$ & $50-70 \%$ \\
\hline ENT & Infrequent & $\begin{array}{c}\text { Frequent (60-80\%): } \\
\text { Destructive Sinusitis, } \\
\text { Saddle-Nose Deformity, } \\
\text { Crusting Rhinitis, Nasal } \\
\text { Septum Deformity, Otitis } \\
\text { Media }\end{array}$ & $\begin{array}{c}\text { Allergic Rhinitis, Sinus } \\
\text { Polyposis }\end{array}$ \\
\hline Lung & $\begin{array}{c}\text { Frequent }(60-80 \%): \\
\text { Cough, Haemoptysis, } \\
\text { Dyspnoea, Interstitial Lung } \\
\text { Pattern, Alveolar } \\
\text { Haemorrhage }\end{array}$ & $\begin{array}{c}\text { Frequent }(60-80 \%) \text { : } \\
\text { Non-Migratory Nodule or } \\
\text { Infiltrates, Excavated Nodules, } \\
\text { Bronchial And/or Subglottic } \\
\text { Stenosis }\end{array}$ & $\begin{array}{l}\text { Asthma (Approximately } \\
\text { 100\%), Migratory Nodules or } \\
\text { Infiltrates, Eosinophil Pleural } \\
\text { Effusion }\end{array}$ \\
\hline \multirow[b]{2}{*}{ Kidney } & \multicolumn{3}{|c|}{ Proteinuria, Haematuria, Renal Failure } \\
\hline & $\begin{array}{c}\text { Frequent }(80 \%) \text { : } \\
\text { Glomerulonephritis }\end{array}$ & $\begin{array}{l}\text { Frequent (60-80\%): } \\
\text { Glomerulonephritis }\end{array}$ & Possible $(20 \%)$ \\
\hline \multirow{2}{*}{ Neurologic } & \multicolumn{3}{|c|}{ Mononeuritis Multiplex, Polyneuropathy, Cranial Nerves Disorders, Pachymeningitis } \\
\hline & Possible (35\%) & Possible (25\%) & Frequent $(65-75 \%)$ \\
\hline \multirow[b]{2}{*}{ Heart } & \multicolumn{3}{|c|}{ Myocarditis, Pericarditis, Ischemia } \\
\hline & & & $\begin{array}{l}\text { Possible }(10-50 \%): \\
\text { From Asymptomatic to } \\
\text { Cardiomyopathy }\end{array}$ \\
\hline \multirow[b]{2}{*}{ Eye } & \multicolumn{3}{|c|}{ Uveitis, Conjunctivitis, Episcleritis } \\
\hline & \multicolumn{3}{|c|}{$\begin{array}{c}\text { Mono or Bilateral Proptosis, } \\
\text { Orbital Tumour }\end{array}$} \\
\hline Venous thrombosis & & $7-8 \%$ & \\
\hline \multirow[t]{2}{*}{ Laboratory } & \multicolumn{3}{|c|}{ Increase ESR and CRP, Anaemia, Thrombocytosis } \\
\hline & & & Eosinophilia \\
\hline cANCA/PR3 & $10-20 \%$ & $80-90 \%$ & \\
\hline pANCA/MPO & $60-85 \%$ & $0-10 \%$ & $\begin{array}{l}30-60 \% \text {, usually } \\
\text { pANCA/MPO }\end{array}$ \\
\hline
\end{tabular}

Legend: MPA, microscopic polyangiitis; GPA, granulomatosis with polyangiitis; EGPA, eosinophilic granulomatosis with polyangiitis; ENT, ear, nose and throat; ESR, erythrocyte sedimentation rate; CRP, C-reactive protein; ANCA, antineutrophil cytoplasmatic antibody; cANCA, cytoplasmic ANCA pattern; PR3, proteinase 3; pANCA, perinuclear ANCA pattern; MPO, myeloperoxidase.

Renal involvement is very common in GPA and MPA, especially at the onset of the disease [2]. Rapidly progressive glomerulonephritis with renal failure associated with proteinuria, microscopic haematuria, and hypertension can be the typical renal presentation [2]. Kidney biopsy typically reveals a pauci-immune focal necrotizing crescent glomerulonephritis [2]. Other histopathological features may include glomerular crescent 
or tubular intraepithelial infiltrates (acute inflammation) as well as glomerulosclerosis or interstitial fibrosis or tubular atrophy (chronic inflammation).

Validated scales to evaluate activity (Birmingham Vasculitis Activity Score (BVAS)) [11], damage (Vasculitis Damage Index (VDI) [12], and disease prognosis (Five-Factor Score (FFS) [13] as well as a questionnaire about quality of life (AAV patient-reported outcomes (AAV-PRO)) [14], are extremely useful to support physicians in their choice of treatment [15].

The prognosis of AAV has greatly improved, and the 5-year survival rate has risen to around $70-80 \%$ over the past $40-50$ years [16]. Several clinical factors influence the outcome, and the FFS can be applied to predict prognosis. Certainly, age and life-threatening disease at onset, for instance pulmonary-renal syndrome, influence the outcome [17]. The risk of end-stage renal disease (ESRD) is closely related with renal function at onset [18], and the findings of kidney biopsy correlate with the severity of renal involvement. The main causes of death in AAV patients are active disease and infections [19]. Additionally, among patients admitted to the intensive care unit for acute manifestations, the main causes of death are flares and infections [20,21]. Knowledge of ANCA specificity improves the classification of patients into distinct outcome categories. Many studies have focused on the sub-classification of AAV phenotypes based on different clusters (i.e., PR3-AAV, MPO-AAV, ANCA-negative). For instance, MPO-ANCA occurs in more than $80 \%$ of patients with isolated crescentic glomerulonephritis, whereas PR3-ANCA is present in more than $80 \%$ of patients with lung cavities or destructive ENT involvement [22]. Evidence of a higher risk of relapse has been found in PR3-AAV patients with renal involvement compared to non-PR3-AAV patients with renal involvement [23]. Patients with MPO-GPA show more frequently limited diseases with no severe organ involvement, a higher prevalence of subglottic stenosis, and fewer relapses than patients with PR3-GPA [22]. The highest mortality risk is observed in AAV patients with gastrointestinal (GI) and cardiovascular involvement [24]. ANCA-negative EGPA is more prone to cardiovascular involvement and experiencing higher mortality than ANCA-positive EGPA [24]. Nevertheless, up to $30 \%$ of AAV patients are ANCA-negative [24]. Several possible explanations are proposed, including the timing of ANCA testing, the presence of other pathogenic autoantibodies, the variable sensitivity of ANCA detection methods, and the presence of ANCA inhibitors that interfere with their identification.

Table 1 summarizes the main clinical features of AAV [3,25-28].

\section{Pathogenesis of AAV: Which Are the Actors and What Is the Role of B Cells?}

Regarding the pathogenesis of AAV, it can be observed that ANCA, B and T lymphocytes, endothelial cells, monocytes, and the alternative complement pathway play several roles.

It is suggested that triggering events produce an inflammatory response with an over-activation of the immune system, resulting in tissue damage [29]. Infections, genetic background, and environmental agents are involved [7].

The connection between infections and AAV is proposed by several studies. Higher relapse rates of GPA are observed in nasal carriers of Staphylococcus aureus [30]. Recently, Rhee et al. found associations between Corynebacterium tuberculostearicum and Staphylococcus species, including S. aureus in GPA, and demonstrated a local competitive growth between Corynebacteria and Staphylococci at the nasal mucosal level, possibly leading to GPA relapse in hosts predisposed to autoimmunity and ANCA production [31].

Ethnic studies and genome-wide association studies (GWAS) clearly support the view of a vital genetic role in the aetiology of AAV [32]. Interestingly, the associations with HLA (DQ in MPA), SERPINA1 (in GPA), and PRTN3 (in GPA) were primarily aligned with ANCA specificity rather than with the clinically defined GPA and MPA syndromes [32].

An interesting link has been established between the disease and latitudinal gradient, which may suggest that ultraviolet radiation has a role in the pathogenesis of EGPA and GPA [33]. Other potential risk factors for the development of AAV are silica exposure [34] and some drugs, including propylthiouracil, hydralazine, minocycline, and levamisole- 
adulterated cocaine [35]. Recently, three other new drugs (i.e., mirabegron, sofosbuvir, and nintedanib) have been identified as potential causes of AAV [36].

Following the exposure to such risk factors or other unknown events, the inflammatory response starts. The presence of a peptide that is complementary to an autoantigen (PR3 or MPO) is the trigger for the production of the anti-idiotype response (ANCAs antibodies) by the B cells [29]. This process is enhanced by imbalances in different $\mathrm{T}$ cell subtypes, and the cytokine-chemokine network participates in the break of tolerance and triggers autoimmunity.

Inflammatory cytokines and complement systems (i.e., the alternative complement pathway, thought C5a) primed neutrophils with the movement of MPO and PR3 to the cell surface. Then, circulating ANCAs activate neutrophils, thus conditioning an excessive and sustained presentation of PR3 or MPO at the level of the cell surface and the extracellular space. Consequently, neutrophils undergo margination, adhesion, transmigration, and oxidative stress, leading to chromatin networks in the vascular wall known as neutrophil extracellular traps (NETs) [29]. Lymphocyte function-associated antigen-1 (LFA-1) and intercellular adhesion molecule-1 (ICAM1), which are implicated in the neutrophil adhesion and migration process, might be potential therapeutic targets since the expression of LFA-1 in the neutrophils from patients with AAV is increased, and LFA-1 levels show clinical correlations [37].

Finally, NETs induce endothelial damage, apoptosis, and necrosis; moreover, the maintenance of high inflammatory levels allows for the formation of micro-abscesses and necrotizing granulomas that are rich in monocytes and macrophages [29].

Thus, B cells with their consequent ANCA production are among the major players in $\mathrm{AAV}$ pathogenesis, supporting the use of therapeutic strategies directly targeting $\mathrm{B}$ cells. Additionally, in AAV, B-cells can pathogenetically act as antigen-presenting cells as well as proinflammatory producing cells and infiltrating inflammatory cells in the tissues. Rituximab (RTX) is a chimeric monoclonal antibody that can reduce inflammation and tissue damage due to selective B cell depletion, targeting CD20 molecules on the surface of pre-B and mature B-lymphocytes. Several observational studies have provided evidence for the safety and efficacy of RTX in many autoimmune systemic diseases, including systemic vasculitis other than AAV $[38,39]$. In the last ten years, RTX has been successfully trailed in $\mathrm{AAV}$ for the induction and maintenance of remission [40-47].

\section{Rituximab in Inducing Remission}

In 2011, RTX was approved by the Food and Drug Administration (FDA) at the dose of $375 \mathrm{mg} / \mathrm{m}^{2}$ intravenous (IV) per week for 4 weeks along with glucocorticoids (GC) in the treatment of patients with GPA and MPA [45,46]. There were two randomized trials, RAVE [40] and RITUXVAS [41], that have demonstrated that RTX is not inferior to cyclophosphamide (CYC) in inducing remission in both new and relapsed patients with GPA and MPA.

The RAVE [40] study was a multicentre, randomized (1:1), double-blind trial. It compared RTX at the dose of $375 \mathrm{mg} / \mathrm{m}^{2}$ weekly for 4 weeks and oral CYC ( $2 \mathrm{mg}$ per kilogram of body weight per day) in inducing remission in patients with GPA and MPA. The primary endpoint was a BVAS of 0 with the successful completion of prednisone taper at 6 months. Of the patients in the RTX group, 63/99 (64\%) reached the primary endpoint, as compared to $52 / 98(53 \%)$ patients in the control group. The difference between the two groups was not significant $(p=0.09)$ but met the criterion for non-inferiority $(p<0.001)$. The RAVE trial demonstrated that RTX was superior to CYC in relapsing disease, in fact, $34 / 51(67 \%)$ patients in the RTX group reached the primary endpoint versus $21 / 50(42 \%)$ in the control group, $p=0.01$. In addition, a difference in the loss of ANCA reactivity was observed: $51 \%$ of patients in the RTX group became PR3-ANCA negative versus $17 \%$ of the control group $(p<0.001)$. There were no significant differences in the number of total adverse events between the two groups; nevertheless, more patients in the control group 
had one or more adverse events ( $33 \%$ versus $22 \%, p=0.01$ ). At 18 months, it was confirmed that RTX is not inferior to CYC $(p<0.001)$ in achieving remission [48].

The RITUXVAS [41] study was a 12-month, randomized (3:1) controlled trial that involved 44 patients with newly diagnosed renal involvement of AAV. Successively, it was extended to a 24-month randomized controlled trial [49]. Patients received GC plus either RTX (375 mg $/ \mathrm{m}^{2}$ per week for 4 weeks) with two CYC IV pulses or CYC IV for 3-6 months followed by AZA. There was no difference in the primary composite outcome of death, endstage renal disease (ESRD), and relapse between the two groups at 24 months. Cumulative renal survival rates reached $93 \%$ in the RTX group and 100\% in the control group $(p=0.39)$. Adverse event rates were comparable in the two groups. The abovementioned randomized controlled trials investigating rituximab as induction in AAV are summarized in Table 2.

Table 2. Main characteristics and results of randomized trials using rituximab as induction in AAV.

\begin{tabular}{|c|c|c|c|c|c|}
\hline Name & Population & Number of Patients & Primary Endpoint & Results & Other Findings \\
\hline RAVE [40] & $\begin{array}{c}\mathrm{N}=197 \mathrm{pts} ; \\
\text { GPA or MPA; } \\
\text { new onset (49\%) or } \\
\text { relapsing disease; } \\
\text { ANCA+ }\end{array}$ & $\begin{array}{l}\text { RTX arm: } 99 \text { pts } \\
\text { received } 4 \text { weekly } \\
\text { RTX } 375 \mathrm{mg} / \mathrm{m}^{2} ; \\
\text { Control arm: } 98 \text { pts } \\
\text { received PO CYC } \\
\text { followed by AZA; } \\
\text { same GCs regimen; } \\
\text { randomized 1:1 }\end{array}$ & $\begin{array}{c}\text { Remission of } \\
\text { disease without } \\
\text { GCs at } 6 \text { months }\end{array}$ & $\begin{array}{c}\text { (1) RTX was } \\
\text { noninferior to CYC } \\
(64 \% \text { vs. } 53 \%) \text { at } \\
\text { remission induction } \\
\text { at } 6 \text { months } \\
(p<0.001) \\
\text { (2) RTX was superior } \\
\text { to CYC } \\
(67 \% \text { vs. } 42 \%) \text { in } \\
\text { relapsing disease } \\
(p=0.01)\end{array}$ & $\begin{array}{l}\text { (a) } 50 \% \text { of pts in } \\
\text { RTX arm became } \\
\text { negative for } \\
\text { PR3-ANCA, as } \\
\text { compared with } \\
\text { only } 17 \% \text { in the } \\
\text { control arm; } \\
\text { (b) similar AEs }\end{array}$ \\
\hline RITUXVAS [41] & $\begin{array}{c}\mathrm{N}=44 \mathrm{pts} ; \\
\text { GPA or MPA; } \\
\text { new onset of renal } \\
\text { AAV }\end{array}$ & $\begin{array}{l}\text { RTX arm: } 33 \text { pts } \\
\text { received two doses } \\
\text { CYC IV plus } \\
4 \text { weekly RTX } \\
375 \mathrm{mg} / \mathrm{m}^{2} ; \\
\text { Control arm: } 11 \text { pts } \\
\text { received IV CYC } \\
\text { followed by AZA; } \\
\text { same GCs regimen; } \\
\text { randomized 3:1 }\end{array}$ & $\begin{array}{c}\text { Sustained } \\
\text { remission rates at } \\
12 \text { months and } \\
\text { severe AEs }\end{array}$ & $\begin{array}{c}\text { (1) Equivalent } \\
\text { results in achieving } \\
\text { sustained remission } \\
(76 \% \text { vs. } 82 \%, \\
p=0.68) \\
\text { 2)Severe adverse } \\
\text { events were similar } \\
(42 \% \text { vs. } 36 \%, \\
p=0.77)\end{array}$ & $\begin{array}{l}\text { (a) Sustained } \\
\text { remission rates } \\
\text { were high in both } \\
\text { groups }\end{array}$ \\
\hline
\end{tabular}

Legend: MPA, microscopic polyangiitis; GPA, granulomatosis with polyangiitis; RTX, rituximab; AZA, azathioprine; CYC, cyclophosphamide; AAV, ANCA-associated vasculitis; GCs, glucocorticoids; AEs, adverse effects.

Interestingly, even if the primary objective of PEXIVAS trial was to verify the advantage of plasma exchange (PEX) combined with RTX or CYC in AAV [50], it was the first trial in which patients with GPA or MPA suffering from severe renal vasculitis or diffuse alveolar haemorrhage received RTX associated with PEX. Importantly, the reduced-dose regimen of glucocorticoids tested in PEXIVAS was noninferior to a standard-dose regimen with respect to death or ESRD, while serious infections at 1 year were less common in the reduced-dose group than in the standard-dose group [48]. Thus, a glucocorticoid regimen is the most important modifiable variable that conditions the risk of infection, regardless the drug used in the induction.

Of note, published trials on RTX have not included EGPA. EGPA remains a relatively understudied group of $\mathrm{AAV}$, owing to its relative rarity and phenotypic difference from GPA and MPA. Recently, two systematic reviews about the use of RTX in EGPA have been published [51,52], according to which RTX shows efficacy in inducing remission in both new-onset and relapsing EGPA. Results showed a greater benefit in EGPA with ANCA positivity. Nevertheless, more studies focusing on the use of RTX in EGPA are needed.

\section{Rituximab in Maintaining Remission}

RTX is also recommended in maintaining remission in patients with GPA and MPA $[2,53]$. 
The MAINRITSAN trial [42] randomized 115 patients with newly diagnosed (92/115) or relapsing (23/115) AAV (excluding EGPA) who received a maintenance regimen based on either RTX (500 mg on days 0 and 14 and at months 6,12 , and 18) or a daily azathioprine (AZA) dose until month 22. All of the patients were in complete remission after a CYC-GC regimen, and the primary endpoint was the rate of major relapse at month 28. At month 28, major relapse had occurred in 17 patients in the AZA group $(17 / 58,29 \%)$ and in 3 patients in the RTX group (3/57, 5\%) (HR for relapse, $6.61 ; 95 \% \mathrm{CI}, 1.56$ to $27.96 ; p=0.002$ ). The study showed the superiority of this RTX regimen over azathioprine (AZA) in relapse prevention up to a follow-up of 60 months [54].

The MAINRITSAN2 trial [43] compared the fixed-schedule RTX (500 mg on days 0 and 14 and at months 6,12 , and 18) with an individually tailored RTX maintenance regimen (500 mg on days 0 and 14, further $500 \mathrm{mg}$ based on a 3-monthly measure of ANCA and B cells but only in cases where CD19 + B lymphocytes or ANCA reappeared or ANCA titre rose markedly based on trimestral testing until month 18$)$. The low relapse rates observed in the two arms after 28 months did not differ significantly (13/81 relapsed patients in tailored-infusion versus 8/81 relapsed patients in fixed-schedule-infusion, $p=0.22$ ) and were comparable with the MAINRITSAN trial. The MAINRITSAN2 trial demonstrated that it is possible to maintain remission with fewer infusions. Nevertheless, the role of ANCA as a marker of relapse remains a source of debate, and relapses have been also observed in cases of ANCA negativity and B cell depletion; therefore, actually fixed interval dosing has been recommended [53]. In selected patients after 2 years of maintenance therapy, relapse risk remains high, or relapse may be very risky due to the type of clinical involvement, and extended RTX maintenance therapy should be considered (500-1000 mg every 6-12 months for up to 5 years) [53].

The recently published MAINRITSAN3 trial [44] shows that prolonging RTX treatment (500 mg infused every 6 months for an additional 18 months) after an initial 18-month maintenance regimen was effective in sustaining remission. The relapse-free survival at 28 months was $96 \%$ in the RTX group versus $74 \%$ in the control group (HR 7.5, CI, 1.67 to $33.7, p=0.008)$. The relapse occurred in $2 / 50$ patients in the RTX group versus $12 / 47$ patients in the control group. Among the 12 relapsed patients in the placebo group, $10(83 \%)$ had GPA, $2(17 \%)$ had MPA, 6 were having their first relapse, and all had ANCA positivity (10 PR3-ANCA, 2 MPO-ANCA positivity). In MAINRITSAN3, the relapses seemed to occur more frequently in patients with PR3-AAV than in patients with MPO-AAV. This could suggest again the benefits of long-term RTX administration in this subpopulation [44]. Overall, it is becoming increasingly clear that AAV patients with a relapsing disease need different strategies compared to those with a non-relapsing disease.

The RITAZAREM trial $[46,55]$ is an international, multicentre, open-label, randomized controlled trial recruiting only the subgroup of patients with relapsing AAV. It aims to demonstrate the superiority of RTX over AZA in the prevention of relapses in AAV with relapsing disease. In the RITAZAREM trial, relapsing AAV patients were recruited and received induction therapy with RTX and GCs. If patients achieved remission by month 4, they were randomized in a 1:1 ratio and received a maintenance therapy with either RTX (1000 mg every 4 months for 5 doses) or AZA ( $2 \mathrm{mg} / \mathrm{kg} /$ day). Results show that RTX is superior to AZA in preventing disease relapse with a HR of 0.36 (95\% CI $0.23-0.57$, $p<0.001)$. By the 24th month after randomization, relapse occurred in 11/85 (13\%) of patients in the RTX group compared to $32 / 85(38 \%)$ in the AZA group. At least one severe adverse event (SAE) occurred in 19/85 (22\%) patients in the RTX group and in $31 / 85(36 \%)$ patients in the AZA group. Hypogammaglobulinemia $(\operatorname{IgG}<5 \mathrm{~g} / \mathrm{L})$ and non-severe infections were reported in 25/85 (29\%) and 42/85 (49\%) patients in the RTX group, respectively, compared to $21 / 85(25 \%)$ and $41 / 85(48 \%)$ in the AZA group. Notably, long-term data revealed that the effect of higher-dose RTX is not sustained over time, and relapses are very common in $\mathrm{AAV}$, regardless of maintenance agent used [55].

The above-mentioned trials are in Table 3. 
Table 3. Main characteristics and results of randomized trials using rituximab as maintenance in AAV.

\begin{tabular}{|c|c|c|c|c|c|}
\hline Name & Population & Number of Patients & $\begin{array}{l}\text { Primary } \\
\text { Endpoint }\end{array}$ & Results & Other Findings \\
\hline MAINRITSAN [42] & $\begin{array}{c}\mathrm{N}=115 \mathrm{pts} ; \\
\text { GPA or MPA in } \\
\text { remission of } \\
\text { disease after CYC; } \\
\text { ANCA+ }\end{array}$ & $\begin{array}{l}\text { RTX arm: } 57 \text { pts } \\
\text { received RTX } \\
\text { (500 mg every } \\
6 \text { months); } \\
\text { Control arm: } 58 \text { pts } \\
\text { received AZA; } \\
\text { randomized 1:1 }\end{array}$ & $\begin{array}{l}\text { Rate of major } \\
\text { relapse at } \\
\text { month } 28\end{array}$ & $\begin{array}{c}\text { (1) Lower relapse } \\
\text { rate in RTX arm } \\
\text { (5\% vs. } 29 \%, H R \\
\text { for relapse } 6.61 \text {, } \\
\text { IC } 95 \%: \\
1.56-27.96 \\
p=0.002)\end{array}$ & $\begin{array}{l}\text { (a) Similar AEs } \\
(p=0.92)\end{array}$ \\
\hline MAINRITSAN2 [43] & $\begin{array}{c}\mathrm{N}=162 \mathrm{pts} ; \\
\text { GPA or MPA in } \\
\text { remission of } \\
\text { disease; } \\
\text { ANCA+ or ANCA- }\end{array}$ & $\begin{array}{l}\text { Tailored-arm: } 81 \text { pts } \\
\text { patients received a } \\
500 \text { mg RTX infusion } \\
\text { at randomisation, } \\
\text { then in case of } \\
\text { change in ANCA } \\
\text { status or CD19+ B } \\
\text { cell counts exceeded } \\
0 / \mathrm{mm}^{3} \text {; Control arm: } \\
81 \text { pts receiveda } \\
\text { fixed } 500 \text { mg RTX } \\
\text { infusion on days } 0 \\
\text { and } 14 \\
\text { postrandomisation, } \\
\text { then } 6,12, \text { and } 18 \\
\text { months after the first } \\
\text { infusion; } \\
\text { randomized } 1: 1\end{array}$ & $\begin{array}{l}\text { Number of } \\
\text { relapses or } \\
\text { worsening } \\
\text { disease } \\
\text { (BVAS }>0 \text { ) at } \\
\text { month } 28\end{array}$ & $\begin{array}{l}\text { (1) Equivalent } \\
\text { results in } \\
\text { number of } \\
\text { relapses [21 pts } \\
\text { had suffered } 22 \\
\text { relapses: } 14 / 81 \\
(17.3 \%) \text { in } 13 \\
\text { tailored-infusion } \\
\text { recipients and } \\
8 / 81(9.9 \%) \text { in } 8 \\
\text { fixed-schedule } \\
\text { patients } \\
(p=0.22)]\end{array}$ & $\begin{array}{l}\text { (a) AAV relapse rates } \\
\text { did not differ } \\
\text { significantly; } \\
\text { (b) individually } \\
\text { tailored-arm patients } \\
\text { received fewer } \\
\text { rituximab infusions }\end{array}$ \\
\hline
\end{tabular}

(a) Major relapse-free survival estimates at month 28 were $100 \%$ in RTX arm versus $87 \%$ in control arm $(p=0.009)$;

received additional 2 years of RTX over 18 months (4 infusions); Control arm: 47 pts received placebo; randomized 1:1
(1) Relapse-free survival was higher in RTX arm at month 28 ( $96 \%$ vs. $74 \%$, HR 7.5, CI: 1.67-33.7, $p=0.008)$ survival at month 28

(b) lower relapse rate in RTX arm (4\% versus $26 \%$ );

(c) no increase in AEs in extended RTX ( $24 \%$ versus $30 \%$ )

(d) in the placebo arm, relapse is much more common in PR3-ANCA positive pts

(1) RTX was

$$
\mathrm{N}=190 \text { pts; }
$$

relapsed GPA or

MPA re-induced with RTX

RITAZAREM [46,55]

(4 weekly RTX $\left.375 \mathrm{mg} / \mathrm{m}^{2}\right)$ and

in remission of disease at month 4 $(\mathrm{N}=170)$
RTX arm: 85 pts received RTX (1000 mg every 4 months for 5 doses);

Control arm: 85 pts received $A Z A$; randomized 1:1 superior to AZA in relapsing disease with preliminary overall HR estimate of 0.36

(CI 95\%:

0.23-0.57, $p<0.001)$ (a) No increase AEs in RTX arm $(22 \%$ versus $36 \%$ );

(b) relapse is very common in both arms;

(c) the effect of higher-dose RTX is not sustained in long term 


\section{Towards a Patient-Tailored Use of RTX in AAV}

The optimal long-term strategy after fixed-schedule RTX has not been clarified. Several studies have investigated the biomarkers of disease relapse of AAV after RTX treatment. Considering the experience with RTX therapy in other autoimmune diseases, the residual $B$ cells have been investigated. Circulating B cells are detectable in all timepoints using high sensitivity flow cytometry instead of standard flow cytometry [56], and this was linked to the tendency of AAV to relapse, at least in a fraction of patients. Furthermore, specific B-cell populations have different roles in AAV. A reduced risk of relapse has been demonstrated in case of naïve B cell population at 6 months after RTX [57]. By contrast, an increased risk of relapse has been associated with the presence of circulating CD27+ CD38+ plasma cells during disease remission [58]. A combination of B-cell targeting therapies, such as RTX and belimumab, might improve the remission maintenance in PR3-ANCA positive patients [NCT03967925]. Other risk factors for relapsing disease are GPA subtypes, ANCA positivity, especially PR3-ANCA, upper respiratory involvement, and previous relapses [59]. Up to $30 \%$ of patients can show a relapsing or even refractory disease [60], which first requires transition from CYC to RTX or from RTX to CYC. Strategies employed in this group of diseases include a combination of RTX and CYC [61]; RTX, CYC, and PEX [62]; the use of PEX or high-dose intravenous immunoglobulins [63]; or, more recently, complement inhibition [64].

\section{Safety of Rituximab in AAV}

Along with a better prognosis for AAV patients, the safety of long-term therapies has progressively become a primary focus of interest. The optimal balance between AAV therapy risks and benefits is a well-known and persistent challenge.

Infections and infusion reactions are the most common adverse events. The issue of the infections remains open since they still represent the most important cause of hospitalization and mortality, which is sometimes related to secondary hypogammaglobulinemia [65]. Hypogammaglobulinemia following RTX is not uncommon and more likely in patients with high GCs and CYC exposure and low IgG levels at baseline [66,67]. Hypogammaglobulinemia is typically defined as a serum IgG level below $600 \mathrm{mg} / \mathrm{dL}$ and can be further stratified as mild (400-599 mg/dL), moderate (200-399 mg/dL), and severe (0-199 mg/dL). Recommendations for the management of secondary hypogammaglobulinaemia due to B cell targeted therapies in autoimmune rheumatic diseases has recently been published although the strength of the recommendations was limited by the low quality of the evidence and the absence of randomized controlled trials [67]. Notably, immunoglobulin replacement can reduce the infection rate, but not the severe infection rate, in patients with a recurrence of infections [66]. Prophylaxis for Pneumocystis jirovecii during RTX therapy should be considered in all patients, both in the induction and maintenance regimen, and flu and pneumonia vaccination should be encouraged. In fact, the rate of infections can be lowered by trimethoprim-sulfamethoxazole in AAV undergoing RTX [68,69]. Additionally, RTX is considered a risk factor for poor outcomes in the case of SARS-CoV-2 infection [70-72]; thus, AAV patients who need RTX therapy should be recommended to undergo SARS-CoV-2 vaccination before RTX, if possible [70,71].

The incidence of infection with RTX is largely conditioned by the use of concomitant corticosteroids, previous treatments, and comorbidities [44]. The incidence of infectious complications with RTX was as high as with CYC, and this issue needs further investigation [40]. The concomitant use of corticosteroids together with lung comorbidity and diabetes are probably the main drivers for the risk of infections in AAV under RTX, and novel treatment strategies should be aimed to address the issue of sparing corticosteroids in the short and long term [73]. Several ongoing randomized controlled trials are aiming to optimize RTX dosage, possibly in combination with other drugs (CYC or belimumab or avacopan), and to minimize or possibly avoid glucocorticoids (Clinicaltrials.gov. NCT03942887; NCT03967925; NCT03920722; NCT032290456; NCT02749292; NCT02994927). In this regard, very recently, a Japanese phase 4 , multicentre, open-label, randomized, noninferiority 
trial compared two corticosteroid regimens (reduced-dose prednisolone $0.5 \mathrm{mg} / \mathrm{kg} /$ day versus high-dose prednisolone $1 \mathrm{mg} / \mathrm{kg} /$ day) plus RTX $375 \mathrm{mg} / \mathrm{m}^{2} /$ week, four doses in 140 patients with newly diagnosed AAV without severe glomerulonephritis or alveolar haemorrhage. In this trial, there was no difference in the primary endpoint, which was the remission rate at 6 months. Importantly, serious adverse events and, in particular, serious infections occurred at a significantly lower rate in the reduced-dose prednisolone arm [74]. Overall, positive results, if confirmed, will be of major value to improving the safety of the induction regimen with RTX.

Overall, the rate of infusion reactions was low (5\%) [40,75] Infusion related-reactions (IRR) are usually mild to moderate, though fatal evolutions have been reported [40,75]. The most common IRR are fever, rash, itching, and headache [40,75]. More severe IRR includes angioedema, hypotension, and bronchospasm [40,75].

Late delayed neutropenia can usually be observed 6-8 months after RTX treatment, and it is more frequent in GPA (23\%) than in lupus or rheumatoid arthritis [76]. Late-onset neutropenia can be observed in patients with a RTX maintenance regimen and usually recovers without treatment [53]. It is rarely associated with serious infections, which is different from early neutropenia, which is less frequent, but is possibly complicated by serious infections [76].

Data from the European Vasculitis Study Group (EUVAS) demonstrated a 2.8-fold incidence of an increased risk for non-melanoma skin cancer (NMSC) in AAV patients and a non-significant standardized incidence ratio (SIR) for non-NMSC (1.30) than general population expectations [77]. Recently, a propensity score-matched analysis of a nationwide study demonstrated that age, male sex, GPA sub-type, and CYC therapy was associated with cancer risk in AAV [78]. The malignancy risk in patients with AAV was lower in RTX-treated patients than in CYC-treated patients [79]. Notably, RTX treatment was not associated with an increased malignancy risk compared to the general population [79].

Despite the lack of head-to-head trials, retrospective studies supported that similar biologic RTX was as effective and safe as an originator in induction and remission maintenance in patients with AAV [80,81]. A recent systematic review comparing the four-dose ( $375 \mathrm{mg} / \mathrm{m}^{2}$ intravenously weekly) versus the two-dose (1000 mg intravenously biweekly) regimens in AAV did not find any differences for either efficacy or safety [82].

\section{Conclusions}

RTX plays an important role in AAV induction and maintenance therapy, especially in some subgroups of patients (Figure 1). After the introduction of CYC, which significantly improved the survival of AAV [83], the efficacy of RTX in AAV successfully addressed the issues of fertility preservation and the increased risk of malignancy under CYC. A maintenance therapy with RTX can decrease the rate of relapse and, as a consequence, the cumulative dose of corticosteroids. The optimal duration of RTX maintenance remains unknown, and further studies are required. The ANCA antibody seems to be a promising biomarker to guide RTX maintenance since an increased ANCA titre could reflect the incomplete B cell depletion and subclinical disease activity that may still require B-cell depletion [54]. RTX can be considered a long-term treatment for AAV with correctable side effects. Optimizing B cell-depleting therapy and steroid-sparing regimens is the next step towards further improvements in both the mortality rate and quality of life of AAV patients. 



Figure 1. Major drivers, PROS, and CONS for choosing RTX in AVV. Legend: PR3, proteinase 3; CYC, cyclophosphamide; PEX, plasma exchange.

Author Contributions: L.Q. conceived the study. All authors contributed to data collection. The analysis was performed by L.Q., E.T., M.B., R.A., and S.D.V. The first draft of the manuscript was written by L.Q., E.T., and S.D.V., and all authors commented on previous versions of the manuscript. All authors have read and agreed to the published version of the manuscript.

Funding: This research received no external funding.

Institutional Review Board Statement: The study was conducted according to the guidelines of the Declaration of Helsinki and was approved by the Institutional Review Board (or Ethics Committee) of ASUFC (UD), Italy.

Informed Consent Statement: Informed consent was obtained from all subjects involved in the study.

Data Availability Statement: No new data were created or analyzed in this study. Data sharing is not applicable to this article.

Acknowledgments: We thank Milena Bond, for her contribution to data collection.

Conflicts of Interest: The authors declare no conflict of interest.

\section{References}

1. Jennette, J.C.; Falk, R.J.; Bacon, P.A.; Basu, N.; Cid, M.C.; Ferrario, F.; Flores-Suarez, L.F.; Gross, W.L.; Guillevin, L.; Hagen, E.C.; et al. 2012 Revised International Chapel Hill Consensus Conference Nomenclature of Vasculitides. Arthritis Rheum. 2013, 65, 1-11. [CrossRef]

2. Geetha, D.; Jefferson, J.A. ANCA-Associated Vasculitis: Core Curriculum 2020. Am. J. Kidney Dis. 2020, 75, 124-137. [CrossRef] [PubMed]

3. Salvador, F. ANCA Associated Vasculitis. Eur. J. Intern. Med. 2020, 74, 18-28. [CrossRef]

4. Berti, A.; Dejaco, C. Update on the Epidemiology, Risk Factors, and Outcomes of Systemic Vasculitides. Best Pr. Res. Clin. Rheumatol. 2018, 32, 271-294. [CrossRef]

5. Mohammad, A.J.; Jacobsson, L.T.H.; Mahr, A.D.; Sturfelt, G.; Segelmark, M. Prevalence of Wegener's Granulomatosis, Microscopic Polyangiitis, Polyarteritis Nodosa and Churg-Strauss Syndrome within a Defined Population in Southern Sweden. Rheumatology 2007, 46, 1329-1337. [CrossRef] [PubMed]

6. Comarmond, C.; Pagnoux, C.; Khellaf, M.; Cordier, J.-F.; Hamidou, M.; Viallard, J.-F.; Maurier, F.; Jouneau, S.; Bienvenu, B.; Puéchal, X.; et al. Eosinophilic Granulomatosis with Polyangiitis (Churg-Strauss): Clinical Characteristics and Long-Term Followup of the 383 Patients Enrolled in the French Vasculitis Study Group Cohort. Arthritis Rheum. 2013, 65, 270-281. [CrossRef] [PubMed]

7. Watts, R.A.; Mahr, A.; Mohammad, A.J.; Gatenby, P.; Basu, N.; Flores-Suárez, L.F. Classification, Epidemiology and Clinical Subgrouping of Antineutrophil Cytoplasmic Antibody (ANCA)-Associated Vasculitis. Nephrol. Dial. Transpl. 2015, 30 (Suppl. S1), i14-i22. [CrossRef] [PubMed]

8. Quartuccio, L.; Treppo, E.; Valent, F.; De Vita, S. Healthcare and Economic Burden of ANCA-Associated Vasculitis in Italy: An Integrated Analysis from Clinical and Administrative Databases. Intern. Emerg. Med. 2020, 16, 581-589. [CrossRef] [PubMed]

9. Ungprasert, P.; Koster, M.J.; Cheungpasitporn, W.; Wijarnpreecha, K.; Thongprayoon, C.; Kroner, P.T. Inpatient Epidemiology and Economic Burden of Granulomatosis with Polyangiitis: A 10-Year Study of the National Inpatient Sample. Rheumatology 2020, 59, 3685-3689. [CrossRef] [PubMed]

10. Quartuccio, L.; Bond, M.; Isola, M.; Monti, S.; Felicetti, M.; Furini, F.; Murgia, S.; Berti, A.; Silvestri, E.; Pazzola, G.; et al. Alveolar Haemorrhage in ANCA-Associated Vasculitis: Long-Term Outcome and Mortality Predictors. J. Autoimmun. 2020, $108,102397$. [CrossRef]

11. Mukhtyar, C.; Lee, R.; Brown, D.; Carruthers, D.; Dasgupta, B.; Dubey, S.; Flossmann, O.; Hall, C.; Hollywood, J.; Jayne, D.; et al. Modification and Validation of the Birmingham Vasculitis Activity Score (Version 3). Ann. Rheum. Dis. 2009, 68, 1827-1832. [CrossRef] 
12. Exley, A.R.; Bacon, P.A.; Luqmani, R.A.; Kitas, G.D.; Gordon, C.; Savage, C.O.; Adu, D. Development and Initial Validation of the Vasculitis Damage Index for the Standardized Clinical Assessment of Damage in the Systemic Vasculitides. Arthritis Rheum. 1997, 40, 371-380. [CrossRef] [PubMed]

13. Guillevin, L.; Pagnoux, C.; Seror, R.; Mahr, A.; Mouthon, L.; Le Toumelin, P. French Vasculitis Study Group (FVSG) The Five-Factor Score Revisited: Assessment of Prognoses of Systemic Necrotizing Vasculitides Based on the French Vasculitis Study Group (FVSG) Cohort. Medicine 2011, 90, 19-27. [CrossRef] [PubMed]

14. Robson, J.C.; Dawson, J.; Doll, H.; Cronholm, P.F.; Milman, N.; Kellom, K.; Ashdown, S.; Easley, E.; Gebhart, D.; Lanier, G.; et al. Validation of the ANCA-Associated Vasculitis Patient-Reported Outcomes (AAV-PRO) Questionnaire. Ann. Rheum. Dis. 2018, 77, 1157-1164. [CrossRef] [PubMed]

15. Geetha, D.; Jin, Q.; Scott, J.; Hruskova, Z.; Hanouneh, M.; Little, M.A.; Tesar, V.; Seo, P.; Jayne, D.; Pagnoux, C. Comparisons of Guidelines and Recommendations on Managing Antineutrophil Cytoplasmic Antibody-Associated Vasculitis. Kidney Int. Rep. 2018, 3, 1039-1049. [CrossRef] [PubMed]

16. Flossmann, O.; Berden, A.; de Groot, K.; Hagen, C.; Harper, L.; Heijl, C.; Höglund, P.; Jayne, D.; Luqmani, R.; Mahr, A.; et al. Long-Term Patient Survival in ANCA-Associated Vasculitis. Ann. Rheum. Dis. 2011, 70, 488-494. [CrossRef]

17. Berden, A.E.; Ferrario, F.; Hagen, E.C.; Jayne, D.R.; Jennette, J.C.; Joh, K.; Neumann, I.; Noël, L.-H.; Pusey, C.D.; Waldherr, R.; et al. Histopathologic Classification of ANCA-Associated Glomerulonephritis. J. Am. Soc. Nephrol. 2010, 21, 1628-1636. [CrossRef]

18. Sinico, R.A.; Di Toma, L.; Radice, A. Renal Involvement in Anti-Neutrophil Cytoplasmic Autoantibody Associated Vasculitis. Autoimmun. Rev. 2013, 12, 477-482. [CrossRef]

19. Heijl, C.; Mohammad, A.J.; Westman, K.; Höglund, P. Long-Term Patient Survival in a Swedish Population-Based Cohort of Patients with ANCA-Associated Vasculitis. RMD Open 2017, 3, e000435. [CrossRef]

20. Kimmoun, A.; Baux, E.; Das, V.; Terzi, N.; Talec, P.; Asfar, P.; Ehrmann, S.; Geri, G.; Grange, S.; Anguel, N.; et al. Outcomes of Patients Admitted to Intensive Care Units for Acute Manifestation of Small-Vessel Vasculitis: A Multicenter, Retrospective Study. Crit. Care 2016, 20, 27. [CrossRef]

21. Demiselle, J.; Auchabie, J.; Beloncle, F.; Gatault, P.; Grangé, S.; Du Cheyron, D.; Dellamonica, J.; Boyer, S.; Beauport, D.T.; Piquilloud, L.; et al. Patients with ANCA-Associated Vasculitis Admitted to the Intensive Care Unit with Acute Vasculitis Manifestations: A Retrospective and Comparative Multicentric Study. Ann. Intensive Care 2017, 7, 39. [CrossRef]

22. Lionaki, S.; Blyth, E.R.; Hogan, S.L.; Hu, Y.; Senior, B.A.; Jennette, C.E.; Nachman, P.H.; Jennette, J.C.; Falk, R.J. Classification of Antineutrophil Cytoplasmic Autoantibody Vasculitides: The Role of Antineutrophil Cytoplasmic Autoantibody Specificity for Myeloperoxidase or Proteinase 3 in Disease Recognition and Prognosis. Arthritis Rheum 2012, 64, 3452-3462. [CrossRef]

23. Mahr, A.; Katsahian, S.; Varet, H.; Guillevin, L.; Hagen, E.C.; Höglund, P.; Merkel, P.A.; Pagnoux, C.; Rasmussen, N.; Westman, K.; et al. Revisiting the Classification of Clinical Phenotypes of Anti-Neutrophil Cytoplasmic Antibody-Associated Vasculitis: A Cluster Analysis. Ann. Rheum. Dis. 2013, 72, 1003-1010. [CrossRef] [PubMed]

24. Cornec, D.; Gall, E.C.-L.; Fervenza, F.C.; Specks, U. ANCA-Associated Vasculitis-Clinical Utility of Using ANCA Specificity to Classify Patients. Nat. Rev. Rheumatol. 2016, 12, 570-579. [CrossRef] [PubMed]

25. Greco, A.; De Virgilio, A.; Rizzo, M.I.; Gallo, A.; Magliulo, G.; Fusconi, M.; Ruoppolo, G.; Tombolini, M.; Turchetta, R.; de Vincentiis, M. Microscopic Polyangiitis: Advances in Diagnostic and Therapeutic Approaches. Autoimmun. Rev. 2015, 14, 837-844. [CrossRef] [PubMed]

26. Furuta, S.; Iwamoto, T.; Nakajima, H. Update on Eosinophilic Granulomatosis with Polyangiitis. Allergol. Int. 2019, 68, 430-436. [CrossRef]

27. Greco, A.; Marinelli, C.; Fusconi, M.; Macri, G.F.; Gallo, A.; De Virgilio, A.; Zambetti, G.; de Vincentiis, M. Clinic Manifestations in Granulomatosis with Polyangiitis. Int. J. Immunopathol. Pharm. 2016, 29, 151-159. [CrossRef]

28. Pagnoux, C. Updates in ANCA-Associated Vasculitis. Eur. J. Rheumatol. 2016, 3, 122-133. [CrossRef]

29. Jennette, J.C.; Falk, R.J.; Gasim, A.H. Pathogenesis of Antineutrophil Cytoplasmic Autoantibody Vasculitis. Curr. Opin. Nephrol. Hypertens. 2011, 20, 263-270. [CrossRef]

30. Popa, E.R.; Tervaert, J.W.C. The Relation between Staphylococcus Aureus and Wegener's Granulomatosis: Current Knowledge and Future Directions. Intern. Med. 2003, 42, 771-780. [CrossRef]

31. Rhee, R.L.; Lu, J.; Bittinger, K.; Lee, J.-J.; Mattei, L.M.; Sreih, A.G.; Chou, S.; Miner, J.J.; Cohen, N.A.; Kelly, B.J.; et al. Dynamic Changes in the Nasal Microbiome Associated with Disease Activity in Patients with Granulomatosis with Polyangiitis. Arthritis Rheumatol. 2021. [CrossRef]

32. Lyons, P.A.; Rayner, T.F.; Trivedi, S.; Holle, J.U.; Watts, R.A.; Jayne, D.R.W.; Baslund, B.; Brenchley, P.; Bruchfeld, A.; Chaudhry, A.N.; et al. Genetically Distinct Subsets within ANCA-Associated Vasculitis. N. Engl. J. Med. 2012, 367, 214-223. [CrossRef]

33. Mahr, A.; Guillevin, L.; Poissonnet, M.; Aymé, S. Prevalences of Polyarteritis Nodosa, Microscopic Polyangiitis, Wegener's Granulomatosis, and Churg-Strauss Syndrome in a French Urban Multiethnic Population in 2000: A Capture-Recapture Estimate. Arthritis Rheum. 2004, 51, 92-99. [CrossRef]

34. Hogan, S.L.; Cooper, G.S.; Savitz, D.A.; Nylander-French, L.A.; Parks, C.G.; Chin, H.; Jennette, C.E.; Lionaki, S.; Jennette, J.C.; Falk, R.J. Association of Silica Exposure with Anti-Neutrophil Cytoplasmic Autoantibody Small-Vessel Vasculitis: A Population-Based, Case-Control Study. Clin. J. Am. Soc. Nephrol. 2007, 2, 290-299. [CrossRef] 
35. Yang, J.; Yao, L.-P.; Dong, M.-J.; Xu, Q.; Zhang, J.; Weng, W.-W.; Chen, F. Clinical Characteristics and Outcomes of PropylthiouracilInduced Antineutrophil Cytoplasmic Antibody-Associated Vasculitis in Patients with Graves' Disease: A Median 38-Month Retrospective Cohort Study from a Single Institution in China. Thyroid 2017, 27, 1469-1474. [CrossRef]

36. Deshayes, S.; Dolladille, C.; Dumont, A.; Martin Silva, N.; Chretien, B.; De Boysson, H.; Alexandre, J.; Aouba, A. A worldwide pharmacoepidemiological update of drug-associated ANCA-associated vasculitis at the time of targeted therapies. Arthritis Rheumatol. 2021. [CrossRef]

37. Matsumoto, K.; Kurasawa, T.; Yoshimoto, K.; Suzuki, K.; Takeuchi, T. Identification of neutrophil $\beta 2$-integrin LFA-1 as a potential mechanistic biomarker in ANCA-associated vasculitis via microarray and validation analyses. Arthritis Res. Ther. 2021, 23, 136. [CrossRef]

38. Quartuccio, L.; Lombardi, S.; Fabris, M.; Masolini, P.; Saracco, M.; Pellerito, R.; Vita, S.D. Long-Term Effects of Rituximab in Rheumatoid Arthritis. Ann. N. Y. Acad. Sci. 2009, 1173, 692-700. [CrossRef] [PubMed]

39. De Vita, S.; Quartuccio, L.; Isola, M.; Mazzaro, C.; Scaini, P.; Lenzi, M.; Campanini, M.; Naclerio, C.; Tavoni, A.; Pietrogrande, M.; et al. A Randomized Controlled Trial of Rituximab for the Treatment of Severe Cryoglobulinemic Vasculitis. Arthritis Rheumatol. 2012, 64, 843-853. [CrossRef] [PubMed]

40. Stone, J.H.; Merkel, P.A.; Spiera, R.; Seo, P.; Langford, C.A.; Hoffman, G.S.; Kallenberg, C.G.M.; St Clair, E.W.; Turkiewicz, A.; Tchao, N.K.; et al. Rituximab versus Cyclophosphamide for ANCA-Associated Vasculitis. N. Engl. J. Med. 2010, 363, $221-232$. [CrossRef] [PubMed]

41. Jones, R.B.; Tervaert, J.W.C.; Hauser, T.; Luqmani, R.; Morgan, M.D.; Peh, C.A.; Savage, C.O.; Segelmark, M.; Tesar, V.; van Paassen, P.; et al. Rituximab versus Cyclophosphamide in ANCA-Associated Renal Vasculitis. N. Engl. J. Med. 2010, 363, 211-220. [CrossRef]

42. Guillevin, L.; Pagnoux, C.; Karras, A.; Khouatra, C.; Aumaître, O.; Cohen, P.; Maurier, F.; Decaux, O.; Ninet, J.; Gobert, P.; et al. Rituximab versus Azathioprine for Maintenance in ANCA-Associated Vasculitis. N. Engl. J. Med. 2014, 371, 1771-1780. [CrossRef]

43. Charles, P.; Terrier, B.; Perrodeau, É.; Cohen, P.; Faguer, S.; Huart, A.; Hamidou, M.; Agard, C.; Bonnotte, B.; Samson, M.; et al. Comparison of Individually Tailored versus Fixed-Schedule Rituximab Regimen to Maintain ANCA-Associated Vasculitis Remission: Results of a Multicentre, Randomised Controlled, Phase III Trial (MAINRITSAN2). Ann. Rheum. Dis. 2018, 77, 1143-1149. [CrossRef]

44. Charles, P.; Perrodeau, É.; Samson, M.; Bonnotte, B.; Néel, A.; Agard, C.; Huart, A.; Karras, A.; Lifermann, F.; Godmer, P.; et al. Long-Term Rituximab Use to Maintain Remission of Antineutrophil Cytoplasmic Antibody-Associated Vasculitis: A Randomized Trial. Ann. Intern. Med. 2020, 173, 179-187. [CrossRef]

45. Smith, R.M.; Jones, R.B.; Specks, U.; Bond, S.; Nodale, M.; Aljayyousi, R.; Andrews, J.; Bruchfeld, A.; Camilleri, B.; Carette, S.; et al. Rituximab as Therapy to Induce Remission after Relapse in ANCA-Associated Vasculitis. Ann. Rheum. Dis. 2020, 79, $1243-1249$. [CrossRef] [PubMed]

46. Smith, R.; Jayne, D.; Merkel, P. A Randomized, Controlled Trial of Rituximab versus Azathioprine After Induction of Remission with Rituximab for Patients with ANCA-Associated Vasculitis and Relapsing Disease. Arthritis Rheumatol 2019, 71 (Suppl. 10). Available online: https://acrabstracts.org/abstract/a-randomized-controlled-trial-of-rituximabversus-azathioprine-after-induction-of-remission-with-rituximab-for-patients-with-anca-associated-vasculitis-and-relapsingdisease/ (accessed on 19 July 2021).

47. Hassan, R.I.; Gaffo, A.L. Rituximab in ANCA-Associated Vasculitis. Curr. Rheumatol. Rep. 2017, 19, 6. [CrossRef]

48. Specks, U.; Merkel, P.A.; Seo, P.; Spiera, R.; Langford, C.A.; Hoffman, G.S.; Kallenberg, C.G.M.; St Clair, E.W.; Fessler, B.J.; Ding, L.; et al. Efficacy of Remission-Induction Regimens for ANCA-Associated Vasculitis. N. Engl. J. Med. 2013, 369, 417-427. [CrossRef] [PubMed]

49. Jones, R.B.; Furuta, S.; Tervaert, J.W.C.; Hauser, T.; Luqmani, R.; Morgan, M.D.; Peh, C.A.; Savage, C.O.; Segelmark, M.; Tesar, V.; et al. Rituximab versus Cyclophosphamide in ANCA-Associated Renal Vasculitis: 2-Year Results of a Randomised Trial. Ann. Rheum. Dis. 2015, 74, 1178-1182. [CrossRef]

50. Walsh, M.; Merkel, P.A.; Peh, C.A.; Szpirt, W.; Guillevin, L.; Pusey, C.D.; De Zoysa, J.; Ives, N.; Clark, W.F.; Quillen, K.; et al. Plasma Exchange and Glucocorticoid Dosing in the Treatment of Anti-Neutrophil Cytoplasm Antibody Associated Vasculitis (PEXIVAS): Protocol for a Randomized Controlled Trial. Trials 2013, 14, 73. [CrossRef]

51. Menditto, V.G.; Rossetti, G.; Olivari, D.; Angeletti, A.; Rocchi, M.; Gabrielli, A.; Pomponio, G. Rituximab for Eosinophilic Granulomatosis with Polyangiitis: A Systematic Review of Observational Studies. Rheumatol. 2021, 60, 1640-1650. [CrossRef]

52. Akiyama, M.; Kaneko, Y.; Takeuchi, T. Rituximab for the Treatment of Eosinophilic Granulomatosis with Polyangiitis: A Systematic Literature Review. Autoimmun. Rev. 2021, 20, 102737. [CrossRef] [PubMed]

53. Tieu, J.; Smith, R.; Basu, N.; Brogan, P.; D'Cruz, D.; Dhaun, N.; Flossmann, O.; Harper, L.; Jones, R.B.; Lanyon, P.C.; et al. Rituximab for Maintenance of Remission in ANCA-Associated Vasculitis: Expert Consensus Guidelines. Rheumatology 2020, 59, e24-e32. [CrossRef] [PubMed]

54. Terrier, B.; Pagnoux, C.; Perrodeau, É.; Karras, A.; Khouatra, C.; Aumaître, O.; Cohen, P.; Decaux, O.; Desmurs-Clavel, H.; Maurier, F.; et al. Long-Term Efficacy of Remission-Maintenance Regimens for ANCA-Associated Vasculitides. Ann. Rheum. Dis. 2018, 77, 1150-1156. [CrossRef] 
55. Gopaluni, S.; Smith, R.M.; Lewin, M.; McAlear, C.A.; Mynard, K.; Jones, R.B.; Specks, U.; Merkel, P.A.; Jayne, D.R.W. RITAZAREM Investigators Rituximab versus Azathioprine as Therapy for Maintenance of Remission for Anti-Neutrophil Cytoplasm AntibodyAssociated Vasculitis (RITAZAREM): Study Protocol for a Randomized Controlled Trial. Trials 2017, 18, 112. [CrossRef] [PubMed]

56. van Dam, L.S.; Oskam, J.M.; Kamerling, S.W.A.; Arends, E.J.; Bredewold, O.W.; Berkowska, M.A.; van Dongen, J.J.M.; Rabelink, T.J.; van Kooten, C.; Teng, Y.K.O. Highly Sensitive Flow Cytometric Detection of Residual B-Cells After Rituximab in AntiNeutrophil Cytoplasmic Antibodies-Associated Vasculitis Patients. Front. Immunol. 2020, 11, 566732. [CrossRef]

57. Md Yusof, M.Y.; Vital, E.M.; Das, S.; Dass, S.; Arumugakani, G.; Savic, S.; Rawstron, A.C.; Emery, P. Repeat Cycles of Rituximab on Clinical Relapse in ANCA-Associated Vasculitis: Identifying B Cell Biomarkers for Relapse to Guide Retreatment Decisions. Ann. Rheum. Dis. 2015, 74, 1734-1738. [CrossRef]

58. von Borstel, A.; Land, J.; Abdulahad, W.H.; Rutgers, A.; Stegeman, C.A.; Diepstra, A.; Heeringa, P.; Sanders, J.S. CD27+CD38hi B Cell Frequency During Remission Predicts Relapsing Disease in Granulomatosis with Polyangiitis Patients. Front. Immunol. 2019, 10, 2221. [CrossRef]

59. Smith, R.M.; Jones, R.B.; Jayne, D.R.W. Progress in Treatment of ANCA-Associated Vasculitis. Arthritis Res. Ther. 2012, 14, 210. [CrossRef]

60. Yates, M.; Watts, R.A.; Bajema, I.M.; Cid, M.C.; Crestani, B.; Hauser, T.; Hellmich, B.; Holle, J.U.; Laudien, M.; Little, M.A.; et al. EULAR/ERA-EDTA Recommendations for the Management of ANCA-Associated Vasculitis. Ann. Rheum. Dis. 2016, 75, 1583-1594. [CrossRef]

61. McAdoo, S.P.; Medjeral-Thomas, N.; Gopaluni, S.; Tanna, A.; Mansfield, N.; Galliford, J.; Griffith, M.; Levy, J.; Cairns, T.D.; Jayne, D.; et al. Long-Term Follow-up of a Combined Rituximab and Cyclophosphamide Regimen in Renal Anti-Neutrophil Cytoplasm Antibody-Associated Vasculitis. Nephrol. Dial. Transpl. 2019, 34, 63-73. [CrossRef]

62. Cortazar, F.B.; Muhsin, S.A.; Pendergraft, W.F.; Wallace, Z.S.; Dunbar, C.; Laliberte, K.; Niles, J.L. Combination Therapy with Rituximab and Cyclophosphamide for Remission Induction in ANCA Vasculitis. Kidney Int. Rep. 2018, 3, 394-402. [CrossRef]

63. Jayne, D.R.; Chapel, H.; Adu, D.; Misbah, S.; O’Donoghue, D.; Scott, D.; Lockwood, C.M. Intravenous Immunoglobulin for ANCA-Associated Systemic Vasculitis with Persistent Disease Activity. QJM 2000, 93, 433-439. [CrossRef]

64. Jayne, D.R.W.; Bruchfeld, A.N.; Harper, L.; Schaier, M.; Venning, M.C.; Hamilton, P.; Burst, V.; Grundmann, F.; Jadoul, M.; Szombati, I.; et al. Randomized Trial of C5a Receptor Inhibitor Avacopan in ANCA-Associated Vasculitis. J. Am. Soc. Nephrol. 2017, 28, 2756-2767. [CrossRef]

65. Little, M.A.; Nightingale, P.; Verburgh, C.A.; Hauser, T.; De Groot, K.; Savage, C.; Jayne, D.; Harper, L.; European Vasculitis Study (EUVAS) Group. Early mortality in systemic vasculitis: Relative contribution of adverse events and active vasculitis. Ann. Rheum. Dis. 2010, 69, 1036-1043. [CrossRef] [PubMed]

66. Tieu, J.; Smith, R.M.; Gopaluni, S.; Kumararatne, D.S.; McClure, M.; Manson, A.; Houghton, S.; Jayne, D.R.W. Rituximab Associated Hypogammaglobulinemia in Autoimmune Disease. Front. Immunol. 2021, 12, 671503. [CrossRef] [PubMed]

67. Wijetilleka, S.; Jayne, D.R.; Mukhtyar, C.; Ala, A.; Bright, P.D.; Chinoy, H.; Harper, L.; Kazmi, M.A.; Kiani-Alikhan, S.; Li, C.K.; et al. Recommendations for the management of secondary hypogammaglobulinaemia due to $\mathrm{B}$ cell targeted therapies in autoimmune rheumatic diseases. Rheumatology 2019, 58, 889-896. [CrossRef] [PubMed]

68. Kronbichler, A.; Kerschbaum, J.; Gopaluni, S.; Tieu, J.; Alberici, F.; Jones, R.B.; Smith, R.M.; Jayne, D.R.W. TrimethoprimSulfamethoxazole Prophylaxis Prevents Severe/Life-Threatening Infections Following Rituximab in Antineutrophil Cytoplasm Antibody-Associated Vasculitis. Ann. Rheum. Dis. 2018, 77, 1440-1447. [CrossRef] [PubMed]

69. Monti, S.; Delvino, P.; Riboli, M.; Rebuffi, C.; Xoxi, B.; De Silvestri, A.; Montecucco, C. The role of Trimethoprim/sulfametoxazole in reducing relapses and risk of infec-tions in ANCA-associated vasculitis: A meta-analysis. Rheumatology 2021, 22, keab267. [CrossRef]

70. Sparks, J.A.; Wallace, Z.S.; Seet, A.M.; Gianfrancesco, M.A.; Izadi, Z.; Hyrich, K.L.; Strangfeld, A.; Gossec, L.; Carmona, L.; Mateus, E.F.; et al. Associations of baseline use of biologic or targeted synthetic DMARDs with COVID-19 severity in rheumatoid arthritis: Results from the COVID-19 Global Rheumatology Alliance physician registry. Ann. Rheum. Dis. 2021, 80, 1137-1146. [CrossRef]

71. Quartuccio, L.; Treppo, E.; Binutti, M.; Del Frate, G.; De Vita, S. Timing of Rituximab and Immunoglobulin Level Influence the Risk of Death for COVID-19 in ANCA-Associated Vasculitis. Rheumatology 2021, 60, 3476-3477. [CrossRef] [PubMed]

72. Benucci, M.; Quartuccio, L.; Li Gobbi, F.; Damiani, A.; Grossi, V.; Infantino, M.; Manfredi, M. Persistence of RT-PCR-SARS-CoV-2 Infection and Delayed Serological Response, as a Possible Effect of Rituximab According to the Hypothesis of Schulze-Koops et Al. Ann. Rheum. Dis. 2020. [CrossRef]

73. McClure, M.E.; Zhu, Y.; Smith, R.M.; Gopaluni, S.; Tieu, J.; Pope, T.; Kristensen, K.E.; Jayne, D.R.W.; Barrett, J.; Jones, R.B. Long-term maintenance rituximab for ANCA-associated vasculitis: Relapse and infection prediction models. Rheumatology 2021, 60, 1491-1501, PMID: 33141217; PMCID: PMC7937025. [CrossRef] [PubMed]

74. Furuta, S.; Nakagomi, D.; Kobayashi, Y.; Hiraguri, M.; Sugiyama, T.; Amano, K.; Umibe, T.; Kono, H.; Kurasawa, K.; Kita, Y.; et al. Effect of Reduced-Dose vs High-Dose Glucocorticoids Added to Rituximab on Remission Induction in ANCA-Associated Vasculitis: A Randomized Clinical Trial. JAMA 2021, 325, 2178-2187. [CrossRef] [PubMed]

75. Paul, F.; Cartron, G. Infusion-Related Reactions to Rituximab: Frequency, Mechanisms and Predictors. Expert. Rev. Clin. Immunol. 2019, 15, 383-389. [CrossRef] 
76. Tesfa, D.; Ajeganova, S.; Hägglund, H.; Sander, B.; Fadeel, B.; Hafström, I.; Palmblad, J. Late-Onset Neutropenia Following Rituximab Therapy in Rheumatic Diseases: Association with B Lymphocyte Depletion and Infections. Arthritis Rheum. 2011, 63, 2209-2214. [CrossRef]

77. Heijl, C.; Harper, L.; Flossmann, O.; Stücker, I.; Scott, D.G.I.; Watts, R.A.; Höglund, P.; Westman, K.; Mahr, A. European Vasculitis Study Group (EUVAS) Incidence of Malignancy in Patients Treated for Antineutrophil Cytoplasm Antibody-Associated Vasculitis: Follow-up Data from European Vasculitis Study Group Clinical Trials. Ann. Rheum. Dis. 2011, 70, 1415-1421. [CrossRef]

78. Choi, S.T.; Ahn, S.V.; Lee, P.H.; Moon, C.M. The Cancer Risk According to Three Subtypes of ANCA-Associated Vasculitis: A Propensity Score-Matched Analysis of a Nationwide Study. Semin. Arthritis Rheum. 2021, 51, 692-699. [CrossRef]

79. van Daalen, E.E.; Rizzo, R.; Kronbichler, A.; Wolterbeek, R.; Bruijn, J.A.; Jayne, D.R.; Bajema, I.M.; Rahmattulla, C. Effect of Rituximab on Malignancy Risk in Patients with ANCA-Associated Vasculitis. Ann. Rheum. Dis. 2017, 76, 1064-1069. [CrossRef]

80. Mittal, S.; Naidu, G.S.R.S.N.K.; Jha, S.; Rathi, M.; Nada, R.; Minz, R.W.; Sharma, K.; Dhir, V.; Jain, S.; Sharma, A. Experience with Similar Biologic Rituximab in 77 Patients of Granulomatosis with Polyangiitis-a Real-Life Experience. Clin. Rheumatol. 2021, 40, 645-651. [CrossRef]

81. Kwon, H.C.; Kim, M.K.; Song, J.J.; Park, Y.B.; Lee, S.W. Rituximab Biosimilar Prevents Poor Outcomes of Microscopic Polyangiitis and Granulomatosis with Polyangiitis as Effectively as Rituximab Originator. Yonsei. Med. J. 2020, 61, 712-719. [CrossRef] [PubMed]

82. Bénard, V.; Farhat, C.; Zarandi-Nowroozi, M.; Durand, M.; Charles, P.; Puéchal, X.; Guillevin, L.; Pagnoux, C.; Makhzoum, J.P. Comparison of Two Rituximab Induction Regimens for Antineutrophil Cytoplasm Antibody-Associated Vasculitis: Systematic Review and Meta-Analysis. ACR Open Rheumatol. 2021, 3, 484-494. [CrossRef] [PubMed]

83. Fauci, A.S.; Haynes, B.F.; Katz, P.; Wolff, S.M. Wegener's Granulomatosis: Prospective Clinical and Therapeutic Experience with 85 Patients for 21 Years. Ann. Intern. Med. 1983, 98, 76-85. [CrossRef] [PubMed] 